\title{
Menelusuri Kembali Peran Investasi Modal Manusia dan Modal Fisik Dalam Meningkatkan Pertumbuhan Produktivitas
}

\author{
Hendarmin* \\ Fakultas Ekonomi dan Bisnis, Universitas Tanjungpura, Indonesia
}

\begin{abstract}
The purpose of this study is to examine the impact of human capital on the level of economic productivity of regencies/cities in West Kalimantan Province. The data used in this study are panel data from 14 West Kalimantan Province/City Districts during the period 2012-2017 whose research results were analyzed using the Random Effect approach panel data regression analysis. The results of the study explained that the role of hum an capital as measured by the level of education, namely the average length of school (RLS), High School Participation Rate, and health level namely life expectancy (AHH) had a non-significant effect on economic productivity. Whereas physical capital investment (PMTB) has a significant influence on the level of economic productivity. The results of the analysis also show that for the human capital variable it has a smaller magnitude compared to the physical capital investment variable. Based on these results, it is concluded that the impact of human capital is very important in increasing economic productivity in the Regency/City of West Kalimantan Province.
\end{abstract}

JEL: E24, E220, I25, I140

Keywords: human capital, investment, productivity, health, education, random effect methods

\section{PENDAhULUAN}

Upaya meningkatkan pertumbuhan produktivitas merupakan modal utama bagi tumbuh kembangnya ekonomi suatu negara. Dengan demikian pertumbuhan ekonomi yang dicapai oleh suatu negara merupakan fungsi dalam peningkatan produktivitas yang tergambar dari peningkatan output nasional. Agar dapat tumbuh secara berkelanjutan sistem ekonomi suatu negara memerlukan peningkatan produktivitas disetiap sektor atau lapangan usaha utama seperti sektor industri pengolahan, sektor pertanian, sektor jasa, transportasi, komunikasi dan sektor kontruksi. Dimana dalam perkembangangannya produktivitas sektor-sektor tersebut merupakan fungsi dari sejumlah hal yang terkait dengan kualitas sumber daya manusianya seperti kualitas tenaga kerja, tingkat pendidikan, infrastruktur, kebijakan pemerintah (regulasi) serta kepastian adanya stabilitas politik, ekonomi dan keamanan suatu negara.

Upaya untuk mendorong produktivitas ekonomi nasional dilakukan pemerintah melalui peningkatan investasi di dalam negeri seperti pada investasi pembentukan modal tetap bruto atau investasi fisik dalam mempercepat pembangunan infrastruktur diberbagai wilayah seperti pelabuhan, bandar udara, pembangkit listrik, rel kereta api, air bersih, dan jalan raya. Sedangkan

*Email: hendarmin_feuntan@ymail.com

Received: 25-11-2018, Accepted: 21-02-2019, Published: 19-12-2019

P-ISSN : 2087-9954, E-ISSN : 2550-0066. DOI : http://dx.doi.org/10.26418/jebik.v8i3.29813 
dari sisi ketenagakerjaan, upaya untuk meningkatkan produktivitas tenaga kerja dilakukan pemerintah dengan serangkaian kebijakan yaitu pengalokasian anggaran untuk perbaikan kualitas modal manusia baik di bidang pendidikan maupun bidang kesehatan dalam jangka panjang memperluas akses kualitas sumber daya manusia di setiap wilayah. Modal manusia adalah suatu dimensi kualitatif dari sumberdaya insani. Dimensi kualitatif dari sumberdaya insani, yaitu keahlian dan keterampilan, yang dimiliki oleh seseorang akan dapat mempengaruhi kemampuan produktivitas seseorang tersebut. Sedangkan keahlian, keterampilan dan pengetahuan dapat ditingkatkan melalui proses pendidikan yang lebih baik dan kondisi kesehatan yang selalu terjaga.

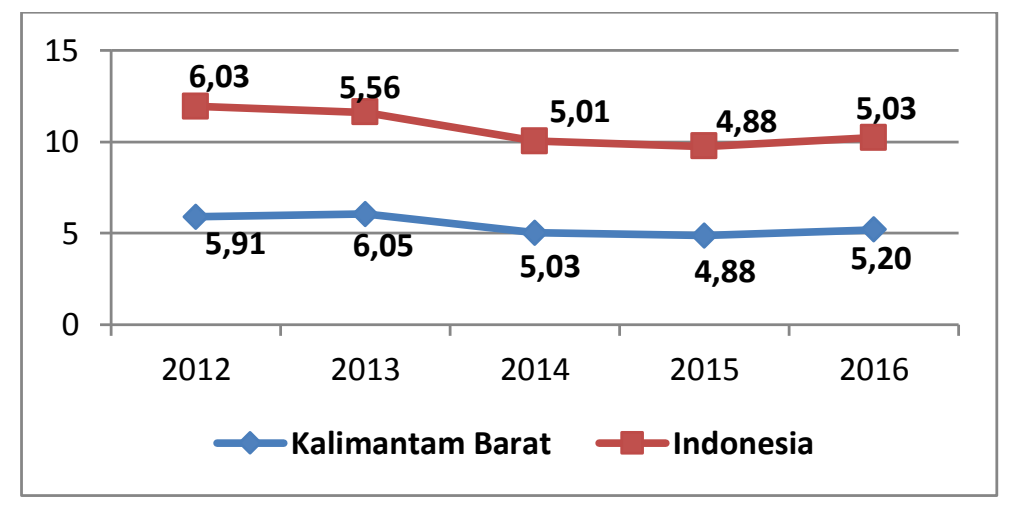

\section{Gambar 1. Pertumbuhan Ekonomi Kalimantan Barat 2012-2016}

Gambar di atas adalah perkembangan tingkat pertumbuhan ekonomi Provinsi Kalimantan Barat selama tahun 2012-2016. Pertumbuhan ekonomi Kalimantan Barat yang ditunjukkan oleh PDRB atas dasar harga konstan 2010 nilainya berfluktuasi. Pada tahun 2014, pertumbuhan ekonomi Kalimantan Barat 5,03 persen. Pada tahun 2015 pertumbuhan ekonomi Kalimantan Barat hanya 4,88 persen. Selanjutnya tahun 2016 tumbuh 5,20 persen Dalam kurun waktu 5 tahun terakhir (2012-2016) perekonomian Kalimantan Barat cukup optimis tumbuh lebih dari 5 persen, kecuali tahun 2015 sedikit melambat tumbuh di bawah 5 persen. Rata-rata pertumbuhan ekonomi Kalimantan Barat selama 5 tahun melebihi pertumbuhan ekonomi Indonesia.

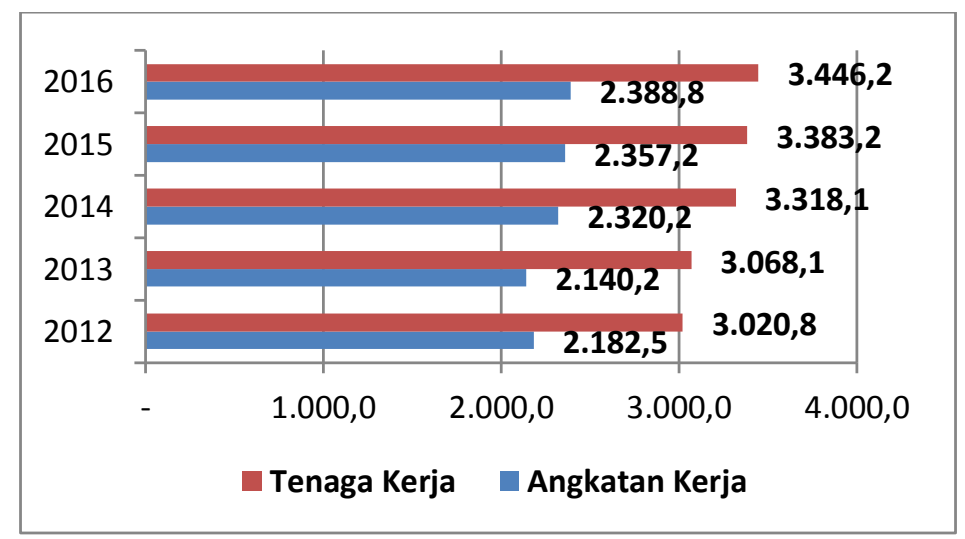

\section{Gambar 2. Jumlah Angkatan Kerja dan Tenaga Kerja di Kalimantan Barat (Ribu Orang)}

Kalimantan Barat merupakan provinsi yang mempunyai penduduk terbesar, yang tentunya tidaklah sulit dalam penyediaan tenaga kerja. Tahun 2016 populasi penduduk 
Kalimantan Barat mencapai lebih dari 4.861 ribu jiwa dengan jumlah penduduk usia produktif mencapai 3.446,2 ribu jiwa atau sekitar 70,88 persen dari total populasi. Jumlah penduduk Kalimantan Barat yang besar juga menjadi kunci sukses bagi peningkatan daya saing. Dengan dukungan peningkatan kualitas pendidikan dan keterampilan, peningkatan produktivitas tenaga kerja dan peningkatan daya saing daerah akan lebih mudah untuk dicapai.Akan tetapi di Kalimantan Barat seiring dengan pertumbuhan jumlah penduduk, jumlah angkatan kerja yang menggambarkan penawaran tenaga kerja, selama lima tahun terakhir cenderung menurun. Data tahun 2016 menunjukkan bahwa ada sekitar 3.446 ribu orang angkatan kerja di Kalimantan Barat, sebanyak 2.388 ribu orang diantaranya tercatat sebagai penduduk yang bekerja (Gambar 2). Dengan kata lain, tingkat kesempatan kerja pada tahun 2016 adalah sebesar 69,30 persen. Angka tersebut sedikit menurun dari kondisi tahun sebelumnya.

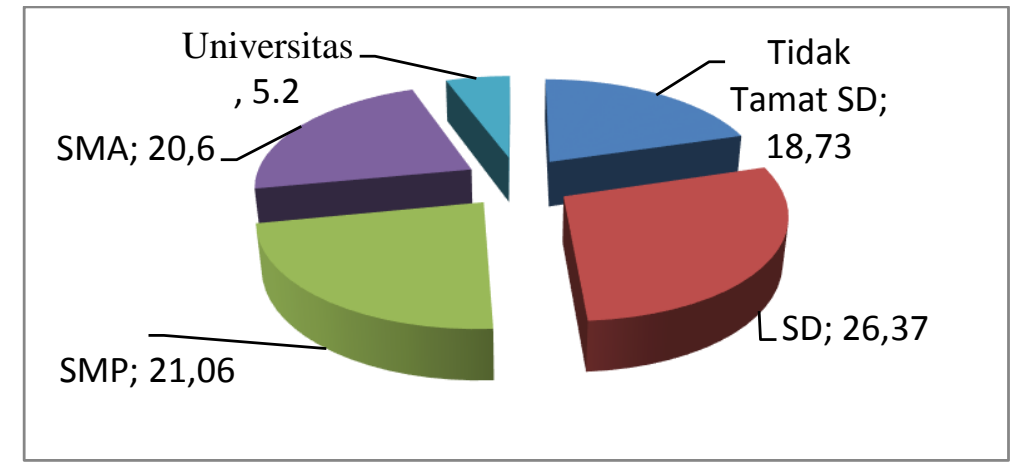

\section{Gambar 3. Persentase Jumlah Penduduk Usia 15 tahun ke atas yang bekerja Menurut Pendidikan yang ditamatkan tahun 2016}

Berdasarkan data Sakernas 2016 menunjukkan bahwa tingkat pendidikan tenaga kerja Kalimantan Barat masih rendah karena sebagian besar berpendidikan SLTP ke bawah mencapai 48,96 persen. Persentase tertinggi hanya berpendidikan tamat SD yaitu sekitar 26 persen. Bahkan yang tidak pernah sekolah hampir mencapai 6 persen dan 18,73 persen tidak tamat SD.

Fenomena di atas menjelaskan bahwa walaupun Provinsi di Kalimantan Barat memiliki pertumbuhan ekonomi yang cukup baik dan perkembangan tingkat pendidikan yang semakin meningkat, tetapi peningkatan pada aspek modal manusia yang terkait dengan kualitas tenaga kerja tersebut masih jauh tertinggal jika dibandingkan dengan provinsi lainnya yang ada di Indonesia. Hal ini yang menjadi alasan bagi penulis untuk melakukan penelitian lebih lanjut dengan melihat aspek dari modal manusia dan peran investasi dalam upaya meningkatkan pertumbuhan produktivitas di Kabupaten/Kota Provinsi Kalimantan Barat. Dengan demikian, penelitian ini bertujuan untuk mengetahui dan menganalisis pengaruh rata-rata lama sekolah, angka partisipasi sekolah tingkat SMA, angka harapan hidup, dan investasi modal fisik terhadap pertumbuhan produktivitas Kabupaten/Kota di Provinsi Kalimantan Barat.

\section{KAJIAN LITERATUR}

\subsection{Tinjauan Teoritis}

Model pertumbuhan ekonomi Neoklasik merupakan salah satu model pertumbuhan yang banyak menjelaskan adanya perbedaan pertumbuhan ekonomi antar negara dan salah satu kontributor utamanya adalah Robert Solow (Todaro \& Smith, 2006). Secara teoritis dasar dari 
teori petumbuhan Solow adalah sisi penawaran dengan menggunakan fungsi produksi sebagai alatnya. Secara sederhana teori ini menyatakan bahwa faktor produksi modal (capital) dan tenaga kerja (labor) merupakan dua faktor penting yang menentukan pertumbuhan ekonomi suatu negara.

Solow (1956) berpendapat bahwa akumulasi modal secara fisik saja tidak cukup untuk menjelaskan adanya perbedaan pertumbuhan ekonomi antar negara. Oleh karena itu model pertumbuhan Solow dirancang untuk menjelaskan bagaimana pertumbuhan dalam persediaan modal, pertumbuhan dalam angkatan kerja, serta kemajuan teknologi berinteraksi dalam perekonomian dan bagaimana pengaruhnya terhadap output total barang dan jasa suatu negara. Namun diasumsikan bahwa tabungan dan kemajuan teknologi adalah eksogen. Jika tabungan meningkat maka investasi meningkat sehingga persediaan modal meningkat. Dengan meningkatnya persediaan modal maka selanjutnya output meningkat akan tetapi pertumbuhan output yang diakibatkan oleh tabungan sifatnya sementara.

Model Solow menggunakan asums-asumsi dengan memfokuskan pada empat variabel yaitu output $(\mathrm{Y})$, modal $(\mathrm{K})$, tenaga kerja (L), dan knowledge atau disebut sebagai efektivitas tenaga kerja (A), pada waktu tertentu (t). Hubungan keempat variabel tersebut jika dinyatakan dalam bentuk fungsi produksi adalah sebagai berikut :

$$
Y(t)=F(K(t), A(t) L(t))
$$

Selanjutnya dalam model pertumbuhan ekonomi neoklasik menjelaskan bahwa output adalah hasil dari modal dan tenaga kerja (Mankiw, 2005; Samuelson \& Nordhaus, 2003). pertumbuhan ekonomi Solow menjelaskan bahwa tingkat tabungan, inovasi teknologi, dan persediaan modal dalam kondisi lapangan kerja penuh adalah faktor-faktor utama dalam mempengaruhi pertumbuhan ekonomic(Mankiw, R., \& Weil., 1992; Mankiw, 2006; Samuelson \& Nordhaus, 2003). Ini menjelaskan bahwa pertumbuhan ekonomi membutuhkan modal akumulasi untuk meningkatkan output nasional. Ekonomi Model pertumbuhan Solow dapat dirumuskan sebagai berikut $\mathrm{Yt}=\mathrm{f}(\mathrm{Lt}, \mathrm{Kt})$ berdasarkan persamaan (2.1) di atas menjelaskan jumlah tersebut modal (Kt) baik modal manusia disertai dengan peningkatan jumlah tenaga kerja (Lt) akan memberi pengaruh pada pertumbuhan ekonomi (Chotib, Suharto, \& Lucik, 2019).

Upaya dalam meningkatkan pertumbuhan ekonomi perlu dilakukan kegiatan ekonomi dengan memanfaatkan beberapa masukan (input), yaitu dengan melakukan aktivitas produksi yang selalu meningkat dengan jalan menambahkan faktor-faktor produksi, seperti modal dan tenaga kerja yang kemudian menghasilkan output dan mempunyai nilai tambah (value added). Selain input, output juga dipengaruhi oleh teknologi yang digunakan dalam proses produksi. Hubungan antara input dan output tersebut dituliskan dalam sebuah fungsi, yang dikenal dengan fungsi produksi. Fungsi produksi adalah hubungan antara jumlah input yang diperlukan dengan jumlah output yang dihasilkan (Samuelson \& Nordhaus, 2003). Fungsi produksi dapat dituliskan :

$$
\mathrm{Q}=\mathrm{f}(\mathrm{K}, \mathrm{L})
$$

dengan $Q$ adalah output barang-barang tertentu selama satu periode, $K$ adalah modal yang digunakan selama periode tersebut, dan $L$ adalah tenaga kerja). Menurut jangka waktunya proses produksi dibagi menjadi fungsi produksi jangka pendek dan fungsi produksi jangka panjang. Dalam proses produksi jangka pendek, sebuah output dapat meningkat melalui 
tambahan satu atau lebih jenis input dengan menganggap seluruh input lainnya adalah konstan. Hal ini dikenal sebagai produktivitas fisik marjinal (Nicholson, 2002).

Produktivitas fisik marjinal dibedakan menjadi dua jenis, yaitu produktivitas fisik marjinal pada modal dan tenaga kerja. Produktivitas fisik marjinal modal (MPK) adalah tambahan output yang diperoleh dari penambahan satu unit modal dengan jumlah tenaga kerja yang konstan. Sebaliknya, produktivitas marjinal tenaga kerja (MPL) adalah tambahan output yang diperoleh dari penambahan input tenaga kerja dengan menganggap konstan peralatan modal. Penambahan input tenaga kerja pada proses produksi akan menyebabkan kenaikan pada output. Akan tetapi, output tersebut akan semakin menurun ketika semakin banyak input tenaga kerja yang ditambahkan. Hal tersebut lebih akrab disebut sebagai produktivitas marjinal yang semakin menurun (diminishing marginal physical productivity). Produktivitas fisik marjinal yang semakin menurun berlaku pada fungsi produksi jangka pendek.

Secara makro, produktivitas adalah rasio antara ukuran output tertentu dibandingkan dengan ukuran input atau sumber daya tertentu (A. McEachern, 2000). Produktivitas dapat mengukur seberapa efisien sumber daya yang digunakan. Hal ini berarti semakin tinggi produktivitas, maka semakin banyak barang dan jasa yang diproduksi dengan jumlah sumber daya tertentu. Produktivitas adalah jumlah barang dan jasa yang diproduksi oleh seorang pekerja setiap jam kerjanya. Pertumbuhan produktivitas adalah kunci untuk dapat meningkatkan standar hidup yang layak bagi suatu negara sebab standar hidup suatu negara tergantung pada kapabilitas seseorang untuk memproduksi barang dan jasa. Menurut Mankiw (2006), beberapa faktor yang menentukan produktivitas adalah antara lain modal fisik (physical capital), modal manusia (human capital), sumber daya alam (natural resources), dan kemampuan pengetahuan dan teknologi para pekerja. Model teoretis yang menjelaskan hubungan antara modal manusia dan pertumbuhan ekonomi dibangun berdasarkan pada hipotesis bahwa pengetahuan dan keterampilan yang ada dalam diri manusia akan meningkatkan produktivitas secara langsung dan meningkatkan kemampuan sebuah perekonomian untuk mengembangkan dan mengadopsi teknologi baru (Fuente, 2011).

Menurut Werigbelegha \& Peter (2018), bahwa modal manusia adalah aset paling berharga baik di negara maju maupun negara berkembang, oleh karena itu modal manusia menjadi salah satu alasan mengapa aset ini perlu dikelola dengan baik dan digunakan secara efektif. Dengan demikian, peran manusia dapat dicapai dengan berkeyakinan bahwa investasi yang dilakukan secara nyata dalam pengembangan sumber daya manusia oleh kelembagan dan pemerintah harus selalu di tingkatkan. Sebuah studi yang dilakukan oleh Oluwatobi \& Ogunrinola (2011) mencerminkan modal manusia sebagai keterampilan kolektif, pengetahuan, dan aset tak berwujud individu yang dapat digunakan untuk menciptakan nilai ekonomi dan peningkatan pada produktivitas. Pentingnya peran modal manusia dalam pencapaian pertumbuhan produktivitas dan pembangunan yang berarti dan berkelanjutan dalam setiap ekonomi modern harus selalu ditekankan (Amassoma \& Nwosa, 2018). Hasil studi dari Aigbokhan, Imahe, \& Ailemen (2017) mengungkapkan bahwa modal manusia diakui sebagai agen nasional pembangunan di semua negara di dunia; dengan memberikan layanan pendidikan dan kesehatan kepada masyarakat dan juga salah satu cara utama untuk meningkatkan kualitas sumber daya manusia. 
Selanjutnya Schultz (1961) dan Mushkin (1962) mengatakan bahwa sumber daya manusia juga dapat diakumulasikan melalui peningkatan di bidang kesehatan. Studi ekonomi makro terbaru yang berfokus pada pertumbuhan, pendapatan per kapita dan pertumbuhan produktivitas, menekankan modal fisik dan modal manusia termasuk pendidikan dan kesehatan sebagai modal utama dan berkelanjutan. Dengan memasukkan modal manusia ke dalam pemodelan makro untuk produktivitas adalah yang pertama dikembangkan oleh Solow (1956) untuk menggabungkan teori pertumbuhan neo-klasik. Dalam pendekatan Solow, pengukuran pertumbuhan produktivitas didasarkan pada produktivitas multi-faktor, dan Solow mengindikasikan sebagai pertumbuhan produktivitas. Ada beberapa asumsi dalam pendekatan ini; pertama, kemajuan teknologi adalah suatu variabel eksogen. Model ini menggunakan standar neo-klasik fungsi produksi dengan menurunnya skala. Kedua, di istilah Solow, pertumbuhan populasi dan tingkat tabungan juga eksogen. Dengan demikian, kedua variabel ini menentukan faktor dalam pendapatan perkapita (Ezoji, Assari, Mahdavi, \& Jahangard, 2019).

Pertumbuhan ekonomi jangka panjang telah menyebabkan kekecewaan yang meluas terhadap teori pertumbuhan tradisional. Model pertumbuhan endogen mempunyai kesamaan secara struktural dengan model Neoklasik, namun sangat berbeda dalam hal asumsi yang mendasarinya serta kesimpulan yang ditarik darinya. Perbedaan teoritis yang paling signifikan berasal dari dikeluarkannya asumsi Neoklasik tentang hasil marjinal yang semakin menurun atas investasi modal, memberikan peluang terjadinya skala hasil yang semakin meningkat (increasing returns to scale) dalam produksi agregat. Teori pertumbuhan endogen berupaya menjelaskan keberadaan skala hasil yang semakin meningkat dan pola pertumbuhan jangka panjang yang berbeda-beda antar negara. Dan karena teknologi masih memainkan peran penting dalam modelmodel ini, perubahan eksogen tidak diperlukan lagi untuk menjelaskan pertumbuhan jangka panjang (Todaro \& Smith, 2006).

Sementara itu, teori pertumbuhan endogen menekankan pada peluang peluang pertumbuhan yang berbeda dalam modal fisik (physical capital) dan modal pengetahuan (knowledge capital). Terdapat diminishing marginal returns bagi modal fisik, namun tidak bagi modal pengetahuan. Pemikiran bahwa meningkatnya investasi dalam pengetahuan akan meningkatkan pertumbuhan adalah kunci untuk menghubungkan tingkat tabungan yang lebih tinggi dengan tingkat pertumbuhan keseimbangan yang lebih tinggi. Jadi dalam teori pertumbuhan endogen berusaha menjelaskan tingkat kemajuan teknologi, yang dalam model Solow disebut variabel eksogen. Model ini berusaha menjelaskan keputusan-keputusan yang menentukan penciptaan ilmu pengetahuan melalui penelitian dan pengembangan. Model Solow kemudian dikembangkan oleh Mankiw et al. (1992) dan Wang \& Yau (2002) dengan masukkan unsur kualitas human capital (quality of human capital) ke dalam model pertumbuhan.

Teori human capital pertama kali diperkenalkan oleh Theodore W. Schultz pada tahun 1961. Schultz (1961) menyatakan bahwa manusia merupakan suatu bentuk modal sebagaimana bentuk modal lain, seperti; mesin dan teknologi. Teori human capital menekankan bahwa pendidikan, pengetahuan, kesehatan, dan keterampilan adalah bentuk modal manusia. Seperti halnya investasi dalam modal fisik, investasi dalam modal manusia menghasilkan return di masa depan. Lebih lanjut Becker (1993) menjelaskan bahwa manusia bukan sekedar sumber daya namun juga merupakan investasi yang menghasilkan pengembalian dan pengeluarannya dilakukan untuk mengembangkan kualitas dan kuantitas manusia. Nilai tambah dalam diri 
manusia tercipta ketika pendidikan dan keterampilan berguna bagi suatu perusahaan. Modal Manusia diukur dengan pendidikan dan pelatihan.

Selanjutnya dalam teori human capital, menyatakan bahwa teori modal manusia pada dasarnya membahas bentuk-bentuk investasi yang bisa ditanamkan kepada manusia, sebab manusia diakui sebagai salah satu sumberdaya yang diperlukan dalam kegiatan produksi barang dan jasa dalam perekonomian (Becker, 1993). Dengan demikian investasi pada modal manusia seperti pendidikan dan kesehatan adalah kunci untuk meningkatkan aspek pembangunan manusia yang pada akhirnya akan meningkatkan output ekonomi bangsa. Secara luas modal manusia memiliki peran penting dalam proses pertumbuhan dan pembangunan ekonomi. Pertumbuhan dan kemajuan ekonomi yang dicapai sangat tergantung kepada peningkatan pembentukan modal baik pembentukan modal fisik maupun modal alam. Selain modal fisik dan modal alam, modal manusia (human capital) juga merupakan faktor yang sangat penting dan merupakan kunci dalam pertumbuhan ekonomi dan dapat meningkatkan produktivitas.

Todaro (2000) mengungkapkan bahwa modal manusia dapat di investasikan melalui bidang pendidikan dan kesehatan. Pendidikan memainkan peran penting dalam hal kemampuan suatu perekonomian untuk mengadopsi teknologi modern dan membangunan sebuah kapasitas bagi pertumbuhan yang berkelanjutan. Kesehatan juga merupakan prasyarat bagi peningkatan produktivitas. Dengan demikian, pendidikan dan kesehatan bisa juga dilihat sebagai komponen vital dalam pertumbuhan dan pembangunan, sebagai input bagi fungsi produksi agregat. Pendidikan dan latihan merupakan faktor penting dalam pengembangan modal manusia. Pendidikan dan latihan dapat menjadi nilai tambah seorang pekerja untuk meningkatkan produktivitas kerja. Pendidikan yang lebih tinggi memungkinkan penghasilan yang tinggi pula untuk seorang pekerja. Dengan demikian, investasi modal manusia dalam bidang pendidikan merupakan faktor yang penting, karena melalui pendidikan akan terlahir modal manusia yang berkualitas sehingga dapat memberikan multiplier effect dan berkontribusi dalam pembangunan perekonomian suatu negara. Selain pendidikan dan latihan, kesehatan juga menunjang pengembangan modal manusia. Kesehatan adalah dasar bagi produktivitas kerja dan kapasitas untuk meningkatkan pendidikan. Tenaga kerja yang sehat secara fisik dan mental akan lebih produktif dalam bekerja dan mendapatkan penghasilan yang tinggi. Kesehatan yang baik merupakan input penting bagi modal manusia dalam meningkatkan produktivitas.

\subsection{Tinjauan Empiris}

\section{Pengaruh Modal Manusia Terhadap Pertumbuhan Produktivitas}

Secara empiris, penelitian mengenai hubungan antara modal manusia dan produktivitas telah banyak dilakukan dan hasil yang diperoleh sangat beragam. Penelitian Ezoji et al. (2019) menganalisis dampak dari hubungan modal manusia (pendidikan dan kesehatan) terhadap produktivitas tenaga kerja. Hasil yang diperoleh adalah ditemukan pengaruh yang positif dan signifikan terhadap produktivitas tenaga kerja dalam jangka panjang. Soltanisehat, Alizadeh, \& Mehregan (2019) menganalisis peran dari pengeluaran untuk penelitian dan pengembangan (R\&D) terhadap pertumbuhan total faktor produktivitas (TFP) pada sektor industri di Negara Iran. Hasil Penelitiannya di simpulkan bahwa variabel untuk pengeluaran bidang penelitian dan pengembangan (R\&D) berpengaruh positif dan signifikan terhadap pertumbuhan total faktor produktivitas (TFP). Arshad \& Malik (2015) dalam studinya meneliti dampak modal manusia terhadap produktivitas tenaga kerja di Malaysia dengan menggunakan analisis data panel. 
Penelitian ini melihat besarnya variabel modal manusia, yang diwakili oleh tingkat pendidikan dan status kesehatan pada produktivitas tenaga kerja. Data panel yang digunakan mencakup 14 negara bagian di Malaysia, mulai dari 2009 hingga 2012.

Hasil penelitian menggunakan pendekatan Fixed Effect Model (FEM) dengan metode Generalized Least Square (GLS). Hasilnya ditemukan bahwa kualitas modal manusia (tingkat pendidikan yang lebih tinggi dan status kesehatan yang lebih baik) berpengaruh positif dan signifikan dalam meningkatkan produktivitas tenaga kerja di Malaysia. Šniukiene \& Matuzeviciute (2018) menganalisis dampak modal manusia terhadap produktivitas tenaga kerja di negara-negara anggota Uni Eropa dengan menggunakan analisis data panel metode Pooled Ordinary Least Square dan pendekatan Fixed Effect Model (FEM). Hasilnya menunjukkan bahwa dampak pengembangan modal manusia yang dinyatakan dalam pengeluaran pendidikan dan kesehatan berpengaruh secara positif dan signifikan terhadap pertumbuhan produktivitas tenaga kerja di Uni Eropa. Amassoma \& Nwosa (2011) melihat hubungan sebab akibat antara investasi modal manusia dan pertumbuhan ekonomi di Negara Nigeria untuk pembangunan berkelanjutan di Afrika pada tahun 1970-2009. Dengan menggunakan Vector Error Correction (VEC) dan metode kausalitas granger berpasangan. Hasil penelitian menunjukkan tidak adanya co-integrasi antara investasi modal manusia dan pertumbuhan ekonomi. Temuan model VAR dan estimasi berpasangan mengungkapkan tidak ada hubungan sebab akibat antara pengembangan modal manusia dan pertumbuhan ekonomi. Studi ini merekomendasikan kebutuhan untuk meningkatkan alokasi anggaran dalam bidang pendidikan dan kesehatan. Oluwadamilola, Akinyemi, \& Adediran (2018) meneliti hubungan antara modal manusia dan pertumbuhan inklusif dan bagaimana mendorong tujuan pembangunan berkelanjutan (SDGs). Penelitian ini menunjukkan bahwa pencapaian SDGs dapat menghasilkan jenis pertumbuhan yang lebih inklusif melalui peran pendidikan yang berkualitas (pengembangan modal manusia).

Eigbiremolen \& Anaduaka (2014) melakukan penelitian dengan menggunakan model pertumbuhan Solow modal manusia untuk melihat dampak modal manusia terhadap output nasional, menggunakan data time series triwulanan tahun 1999-2012. Hasil penelitian sesuai dengan teori yang menunjukkan modal manusia berpengaruh positif dan signifikan terhadap output, hal ini mengindikasikan bahwa peran modal manusia sangat diperlukan dalam pencapaian pertumbuhan ekonomi di negara Nigeria. Namun penelitian dari Anyanwu, Adam, Obi, \& Yelwa (2015) menemukan bahwa modal manusia memiliki dampak positif pada pertumbuhan ekonomi di Nigeria, akan tetapi secara statistik tidak signifikan. Marvelous, Baba, \& Emily (2017) melihat hubungan antara variabel ekonomi yaitu sektor pendidikan terhadap pertumbuhan ekonomi dengan menggunakan model regresi berganda. Hasil penelitian ditemukan bahwa sektor pendidikan memiliki pengaruh positif terhadap pertumbuhan ekonomi di Nigeria. Hal ini berarti pertumbuhan ekonomi dapat ditingkatkan dengan meningkatkan investasi pada modal manusia yaitu bidang pendidikan. Akan tetapi pengeluaran pemerintah untuk pendidikan berhubungan negatif dan signifikan dengan Produk Domestik Bruto di Nigeria. Ozekhome (2018) menggunakan pendekatan dinamis yang melibatkan pengujian untuk unit root, dan kointegrasi, dengan estimasi Generalized Method of Moments (GMM) teknik data time series yang mencakup periode 1981 hingga 2016.

Temuan empiris mengungkapkan bahwa akumulasi modal manusia dan fisik secara signifikan mendorong pertumbuhan ekonomi yang cepat dan berkelanjutan dalam jangka panjang. Maku, Ajike, \& Chinedu (2019) meneliti dampak pengembangan sumber daya manusia 
pada kinerja ekonomi makro Nigeria. Menggunakan model Autoregressive Distributed Lagged (ARDL), penelitian ini menunjukkan hubungan negatif yang tidak signifikan antara pengembangan sumber daya manusia dan PDB per kapita dalam jangka pendek. Hasil ini juga menunjukkan bahwa hanya angka partisipasi sekolah yang secara positif dan signifikan meningkatkan PDB Perkapita. Rangongo \& Ngwakwe (2019) meneliti hubungan antara investasi modal manusia dan pertumbuhan ekonomi di dua negara Afrika sub-Sahara (Kenya dan Afrika Selatan). Pendekatan kuantitatif dan data sekunder dari indikator ekonomi dan pendidikan Bank Dunia dari 1987 hingga 2016 (30 tahun). Hasil menunjukkan bahwa investasi dalam sumber daya manusia berhubungan positif dengan pertumbuhan ekonomi di dua negara Afrika sub-Sahara.

\section{Pengaruh Investasi Modal Fisik Terhadap Pertumbuhan Produktivitas}

Menurut Todaro \& Smith (2006), terdapat tiga komponen pertumbuhan ekonomi yang mempunyai arti penting bagi setiap masyarakat, yaitu (1) akumulasi modal, yang meliputi semua bentuk atau jenis investasi yang ditanamkan pada tanah, peralatan fisik dan modal atau sumber daya manusia; (2) pertumbuhan penduduk, yang beberapa tahun selanjutnya akan memperbanyak angkatan kerja; (3) kemajuan teknologi. Sebagai salah satu komponen pembentuk Produk Domestik Regional Bruto (PDRB), investasi menempati posisi penting dalam mendorong pertumbuhan ekonomi daerah. Sebagai pembentukan modal tetap bruto, pengertian investasi mencakup kegiatan tentang pengadaan, pembuatan, dan pembelian barang-barang modal baru dari dalam negeri/wilayah dan barang modal baru atau bekas dari luar negeri/wilayah, yang digunakan untuk proses produksi di dalam negeri/wilayah tersebut. Peran investasi terhadap pembangunan juga dikemukakan oleh Sollow (Mankiw, 2005). Model pertumbuhan Solow memperlihatkan bagaimana pertumbuhan persediaan modal, pertumbuhan angkatan kerja, kemajuan teknologi berinteraksi dalam perekonomian, serta bagaimana pengaruhnya terhadap output barang dan jasa suatu negara secara keseluruhan. Seperti halnya kebanyakan model pertumbuhan lainnya, model Solow juga menganggap bahwa penawaran dan permintaan terhadap barang memainkan peranan penting dalam suatu perekonomian. Secara teoritis, penawaran barang didasarkan pada fungsi produksi yang menyatakan bahwa persedian output bergantung pada persediaan modal dan angkatan kerja.

Beberapa studi yang telah dilakukan sebelumnya dalam kaitannya dengan investasi modal fisik dan Pertumbuhan ekonomi yang dilaksanakan di berbagai negara. Bassanini, Stefano, \& Philip (2001) menyatakan bahwa determinan pertumbuhan ekonomi merupakan representase dari teori pertumbuhan endogen (New Growth Theory). Secara umum penelitian mereka menunjukan pengaruh investasi fisik dan investasi sumber daya manusia (human capital) yang positif dan signifikan terhadap pertumbuhan pertumbuhan ekonomi (GDP perkapita). Pertumbuhan populasi menunjukan pengaruh yang negatif. Pengeluaran pemerintah (government size) memiliki pengaruh yang signifikan negatif. Aimon (2012), Brata (2002), Farah \& Sari (2014) menemukan bahwa variabel tingkat investasi dalam hal ini investasi modal fisik berdampak positif terhadap pertumbuhan ekonomi.

\section{METODA PENELITIAN}

\subsection{Jenis dan Sumber Data}

Penelitian ini dilakukan di Provinsi Kalimantan Barat, menggunakan data time series dan cross section dengan pendekatan kuntitatif, yaitu berusaha menjelaskan hubungan satu variabel 
dengan variabel yang lain. Data dalam penelitian ini diperoleh dari publikasi resmi Badan Pusat Statistik, Bank Indonesia, Dinas Pendidikan, Badan Perencanaan Pembangunan Nasional (BAPPENAS), dan beberapa dokumen yang berkaitan dengan penelitian ini. Penelitian ini menggunakan metode estimasi Panel Least Square (PLS) untuk menguji dan menganalisis pengaruh investasi modal manusia yang diproksi dengan rata-rata lama sekolah (RLS), angka partisipasi sekolah (APS), angka harapan hidup (AHH), dan Investasi Modal Fisik yang diproksi dengan pembentukan modal tetap bruto (PMTB) terhadap Produktivitas di Kabupaten/Kota Provinsi Kalimantan Barat kurun waktu 2012-2017. Karena penelitian ini menggunakan data gabungan time series dan cross section, maka perlu dilakukan beberapa pengujian yaitu:

\section{Uji Chow}

Chow test (Uji Chow) yakni pengujian untuk menentukan model Fixed Effect atau Random Effect yang paling tepat digunakan dalam mengestimasi data panel. Hipotesis dalam uji chow adalah:

$\mathrm{H}_{0} \quad$ : Common Effect Model atau pooled OLS

$\mathrm{H}_{1} \quad$ : Fixed Effect Model

Dasar penolakan terhadap hipotesis diatas adalah dengan membandingkan perhitungan F-statistik dengan F-tabel. Perbandingan dipakai apabila hasil $\mathrm{F}$ hitung lebih besar (>) dari $\mathrm{F}$ tabel maka $\mathrm{H}_{0}$ ditolak yang berarti model yang paling tepat digunakan adalah Fixed Effect Model. Begitupun sebaliknya, jika $\mathrm{F}$ hitung lebih kecil $(<)$ dari $\mathrm{F}$ tabel maka $\mathrm{H}_{0}$ diterima dan model yang digunakan adalah Common Effect Model (Widarjono, 2007). Perhitungan F statistik didapat dari Uji Chow dengan rumus :

$$
F=\frac{\frac{\left(S S E_{1}\left(S S E_{2}\right)\right)}{(n-1)}}{\frac{S S E_{2}}{(n t-n-k)}}
$$

Dimana :

SSE1 = Sum Square dan Model Common Effect

SSE2 = Sum Square Error dari Model Fixed Effect

$\mathrm{n} \quad=$ Jumlah Perusahaan (cross section)

nt $=$ Jumlah cross section $\mathrm{x}$ jumlah times series

$\mathrm{k} \quad=$ Jumlah variabel independent

Sedangkan F tabel didapat dari :

$$
\mathrm{F}-\text { tabel }=\{\alpha: \mathrm{df}(\mathrm{n}-1, \mathrm{nt}-\mathrm{nk})\}
$$

Dimana :

$\alpha \quad$ : Tingkat signifikansi yang dipakai (alfa)

$\mathrm{N} \quad$ : Jumlah perusahaan (cross section)

nt : Jumlah cross section $\mathrm{x}$ jumlah times series

$\mathrm{k} \quad$ : Jumlah variabel independent 


\section{Uji Hausman}

Setelah selesai melakukan uji Chow dan didapatkan model yang tepat adalah Common Effect, maka selanjutnya kita akan menguji model manakah antara model Fixed Effect atau Random Effect yang paling tepat, pengujian ini disebut sebagai uji Hausman.

Uji Hausman dapat didefinisikan sebagai pengujian statistik untuk memilih apakah model Fixed Effect atau Random Effect yang paling tepat digunakan. Pengujian uji Hausman dilakukan dengan hipotesis berikut:

\section{$\mathrm{H}_{0}:$ Random Effect Model \\ $\mathrm{H}_{1}$ : Fixed Effect Model}

Statistik Uji Hausman ini mengikuti distribusi statistic Chi Square dengan degree of freedom sebanyak $\mathrm{k}$, dimana $\mathrm{k}$ adalah jumlah variabel independen. Jika nilai statistik Hausman lebih besar dari nilai kritisnya maka $\mathrm{H}_{0}$ ditolak dan model yang tepat adalah model Fixed Effect sedangkan sebaliknya bila nilai statistik Hausman lebih kecil dari nilai kritisnya maka model yang tepat adalah model Random Effect.

Uji Chow merupakan alat yang digunakan untuk memilih model antara Fixed Effect dan Common Effect. Berdasarkan pengujian bahwa nilai probabilitas uji chow lebih kecil dari taraf signifikan yang digunakan yaitu $0.0000<0.05$ maka model yang terpilih adalah Fixed Effect. Setelah model Fixed Effect terpilih berdasarkan pada Uji Chow, maka model tersebut dibandingkan kembali dengan model Random Effect dengan Uji Hausman. Berdasarkan pada nilai probabilitas Uji Hausman yang lebih besar dari taraf signifikan yang digunakan yaitu $0.8669<0.05$ maka yang terpilih adalah model random effect (REM).

\section{Uji Normalitas}

Tahap pertama yang dilakukan adalah melihat apakah residual yang kita dapatkan pada model berdistribusi normal atau tidak. Berdasarkan gambar 1.5 bentuk histogram didistribusikan secara semetris dan nilai probabilitas Jarque-Bera melebihi $\alpha=0,05$ maka disimpulkan data berdistribusi normal.

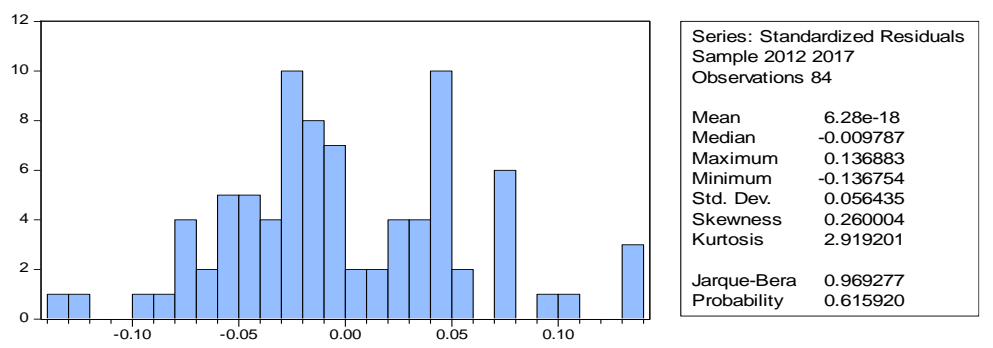

Gambar 4. Histogram Residual

\section{Uji Multikolinieritas}

Sebagimana dijelaskan bahwa pengertian multikolinieritas adalah hubungan linier antara variabel independent di dalam regresi. Oleh karena itu kenapa kita tidak mendeteksi multikolinieritas dengan pengujian koefisien korelasi (r) antar variabel bebas. Sebagai aturan main yang kasar (rule of thumb), jika koefisien korelasi cukup tinggi katakanlah di atas 0,85 maka kita duga ada terjadi multikolinieritas dalam model. Sebaliknya jika koefisien korelasi relatif rendah maka kita duga model tidak mengandung multikolinieritas. 
Tabel 1. Uji Multikolinieritas

\begin{tabular}{ccccc}
\hline & LOG_AHH & LOG_APS & LOG_PMTB & LOG_RLS \\
\hline LOG_AHH & 1 & -0.025767 & -0.331507 & 0.143354 \\
LOG_APS & -0.025767 & 1 & 0.099175 & 0.414679 \\
LOG_PMTB & -0.331507 & 0.099175 & 1 & 0.589638 \\
LOG_RLS & 0.143354 & 0.414679 & 0.589638 & 1 \\
\hline
\end{tabular}

Keberadaan multikolinieritas memiliki dampak yang negatif yaitu varian parameter dapat bernilai lebih besar sebagai konsekuensi dari jumlah sampel yang digunakan relatif sedikit. Adapun konsekuensinya, hasil estimasi memberikan tingkat presisi yang relatif rendah dan mengakibatkan kemampuan yang rendah dalam menolak hipotesis (Wahyudi, 2016). Salah satu metode deteksi masalah multikolinieritas adalah uji korelasi antara variabel independent (bebas) secara individual. Berdasarkan hasil uji di tabel di atas koefisien korelasi relatif rendah maka diduga tidak terdapat multikolinieritas pada model.

\subsection{Metoda Analisis}

Penelitian ini menggunakan metode estimasi Panel Least Square (PLS) untuk menguji pengaruh investasi modal manusia dan investasi modal fisik terhadap pertumbuhan produktivitas, oleh karena itu persamaan regersi data panel adalah sebagai berikut :

$$
Y=f(R L S, A P S, A H H, P M T B) \text {. }
$$

Persamaan-persamaan diatas dapat dinyatakan dalam model ekonometrika untuk menjelaskan tingkat produktivitas terhadap faktor-faktor yang mempengaruhinya yaitu :

$Y_{i t}=\beta_{0}+\beta_{1} R L S_{i t}+\beta_{2} A P S_{i t}+\beta_{3} A H H_{i t}+\beta_{4} P M T B_{i t}+\varepsilon_{i t}$

Dimana :

$\mathrm{Y}_{\text {it }} \quad=$ Pertumbuhan Produktivitas ke-i, pada tahun $\mathrm{t}$

RLS $_{\text {it }} \quad=$ Rata-Rata Lama Sekolah daerah ke-i, pada tahun $t$

APS $_{\mathrm{it}} \quad=$ Angka Partisipasi Sekolah SMA daerah ke-i, pada tahun $\mathrm{t}$

$\mathrm{AHH}_{\mathrm{it}} \quad=$ Angka Harapah Hidup daerah ke-i, pada tahun $\mathrm{t}$

$\mathrm{PMTB}_{\text {it }} \quad=$ Pembentukan Modal Tetap Bruto daerah ke-i, pada tahun $\mathrm{t}$

$\varepsilon_{\text {it }} \quad=$ error term

$\beta_{0} \quad=$ konstanta

$\beta_{1}, \beta_{2}, \beta_{3}, \beta_{4} \quad=$ parameter regresi yang akan diestimasi

$\mathrm{i}=$ wilayah Kabupaten/Kota di Provinsi Kalimantan Barat yang akan diobservasi

$\mathrm{t} \quad=$ periode observasi

\section{HASIL PENELITIAN DAN PEMBAHASAN}

\subsection{Estimasi Model Persamaan Regresi Data Panel}

Setelah model persamaan regresi data panel di atas lolos uji asumsi klasik yaitu : uji normalitas, uji multikolinieritas, uji chow dan uji hausman. Maka sesuai dengan hasil uji spesifikasi Hausman (Hausman Spesifikasi Test), dapat dilihat hasil estimasi model persamaan 
regresi data panel untuk mengetahui pengaruh investasi modal manusia dan investasi modal fisik terhadap pertumbuhan produktivitas yang dilakukan dengan menggunakan pendekatan Random Effect Model (REM).

Tabel 2. Estimasi Model Persamaan Regresi Data Panel Pendekatan Random Effect Model (REM)

\begin{tabular}{cccc}
\hline \multirow{2}{*}{$\begin{array}{c}\text { Variabel } \\
\text { Independent }\end{array}$} & \multicolumn{3}{c}{ Variabel Dependent } \\
\cline { 2 - 4 } & Koefisien & t-stat & P-Value \\
\cline { 2 - 4 } & -1.033261 & -0.526441 & 0.6001 \\
C & 0.238938 & 0.595612 & 0.5531 \\
LOG_RLS? & 0.167532 & 1.131405 & 0.2613 \\
LOG_APS & 0.115878 & 0.114913 & 0.9088 \\
LOG_AHH? & 0.314096 & $3.799684^{*}$ & 0.0003 \\
LOG_PMTB? & & 0.3032050 & \\
R & & 0.000008 & \\
Prob (F-statistic) & & &
\end{tabular}

Keterangan :* $\alpha=5 \%$

Berdasarkan Tabel 2 diperoleh estimasi persamaan regresi data panel dalam penelitian ini sebagai berikut :

$\log Y_{i t}=-1,033+0,238 \log R L S_{i t}+0,167 \log A P S_{i t}+0,115 \log A H H_{i t}+0,314 \log P M T B_{i t}$

Konversi data ke dalam logaritma dilakukan dengan tujuan untuk memperkecil nilai variabel sehingga ada keseimbangan nilai antara satu variabel dengan variabel lainnya dan juga untuk melihat persentase perubahan elastisitas dari setiap variabel yang akan di analisis. Para ahli ekonometrika seringkali melakukan cara tersebut untuk mengatasi permasalahan data agar mempermudah dalam analisis hasil penelitiannya (Gujarati, 2004).

\subsection{Pengaruh Investasi Modal Manusia Terhadap Pertumbuhan Produktivitas}

Hasil estimasi regresi data panel, variabel investasi modal manusia yang diukur dengan rata-rata lama sekolah (RLS), angka partsipasi sekolah SMA dan angka harapan hidup (AHH) berpengaruh positif dan tidak signifikan terhadap tingkat produktvitas Kabupaten/Kota di Provinsi di Kalimantan Barat. Keadaan ini menunjukkan bahwa perubahan variabel investasi modal manusia belum mampu menjelaskan variasi perubahan tingkat produktivitas Kabupaten/Kota di Provinsi Kalimantan Barat selama kurun waktu periode penelitian. Pengaruh yang tidak signifikan antara investasi modal manusia yang dilihat pada rata-rata lama sekolah, angka partisipasi sekolah SMA dan angka harapan hidup mengindikasikan bahwa Angka Partisipasi Sekolah (APS) usia 7-12 tahun dan 13-15 tahun (pendidikan dasar) tahun selama tahun penelitian antar kota dan kabupaten di Provinsi Kalimantan Barat belum merata Rata-rata APS Provinsi Kalimantan Barat tahun sebesar 96,86 persen untuk usia 7-12 tahun dan 85,65 persen untuk usia 13-15 tahun. Kabupaten di Provinsi Kalimantan Barat dengan APS terendah meliputi Kabupaten Malawai, Kab. Kayong Utara, Kab. Sanggau. Semakin tinggi tingkat pendidikan APS semakin kecil. Rendahnya capaian APS pendidikan dasar usia 7-12 tahun dan 13-15 tahun berdampak pada rendahnya rata-rata lama sekolah (RLS) dan angka melek huruf 
(AMH) sebagai indiktor keberhasilan pembangunan oleh MDGs di Provinsi Kalimantan Barat. Angka Melek Huruf (AMH) Provinsi Kalimantan Barat tahun berkisar pada angka 89-91 persen dan tidak banyak peningkatannya, lebih rendah daripada AMH nasional yang terus meningkat dari 92,58 persen. Rendahnya AMH dan RLS di Provinsi Kalimantan Barat antara lain disebabkan kondisi Kalimantan Barat dengan aksesibilitas yang masih rendah sehingga pertumbuhan pencapaian komponen AMH dan RLS berjalan lambat.

Dampak dari rendahnya APS, AMH, serta RLS mempengaruhi produktivitas tenaga kerja di Provinsi Kalimantan Barat. Di samping itu Angkatan kerja di Provinsi Kalimantan Barat memiliki tingkat pendidikan yang rendah sehingga Kalimantan Barat berada dalam ekonomi dengan produktivitas rendah. Di sisi lain, faktor kesehatan merupakan salah satu kebutuhan penting untuk pembangunan manusia. Penyediaan fasilitas kesehatan menjadi salah satu upaya dalam meningkatkan pembangunan kesehatan di Provinsi Kalimantan Barat. Tingkat kesehatan masyarakat Kalimantan Barat belum menunjukkan hasil yang baik apabila dilihat dari indikator kesehatan, seperti angka kematian ibu, angka kematian bayi dan balita, serta gizi buruk yang masih terjadi. Angka kematian bayi di Kalimantan Barat sebanyak 31 kematian per 1000 kelahiran baru, sedangkan angka nasional menunjukkan 34 kematian per 1000 kelahiran baru, beberapa jumlah layanan kesehatan telah tersedia, namun aksesibilitas dan jangkauan pelayanan kesehatan masyarakat masih rendah.

Koefisien variabel investasi modal manusia yang diproksi dengan rata-rata lama sekolah, angka partisipasi sekolah SMA dan angka harapan hidup memiliki arah yang positif dan tidak signifikan terhadap pertumbuhan produktivitas. Hasil penelitian ini sejalan dengan Anyanwu et al. (2015) dan Wang \& Liu (2016) ditemukan bahwa modal manusia memiliki dampak positif pada pertumbuhan ekonomi di Nigeria, akan tetapi secara statistik tidak signifikan. Leeuwen (2007) mengukur modal manusia dengan rata-rata lama bersekolah. Analisis yang dilakukan dengan metode runtut waktu menunjukkan adanya hubungan positif antara modal manusia dan pertumbuhan ekonomi di Indonesia. Vidyattama (2010) dan Kataoka (2013) dengan menggunakan rata-rata lama bersekolah penduduk usia kerja sebagai indikator modal manusia dan menemukan pengaruh positif modal manusia terhadap pertumbuhan ekonomi provinsi. Namun hasil penelitian ini berbeda dengan Aldosari et al. (2014), Bloom, Canning, \& Sevilla (2001), Hakooma \& Seshamani (2017), Islam et al. (2016), Ismail, Saukani, \& Bakar (2014), Ismail \& Yussof (2010) di Arab Saudi, studi oleh Xiaoqing (2005) di Cina dan Arshad \& Malik (2015) di Malaysia, Ahmadi, Naji, \& Jandaghi (2010), Hansen (2013), Raeispour \& Pajooyan (2013), Saha (2013), Shahraki \& Ghaderi (2015), Tang, Foon, \& Yew (2011) yang menyimpulkan bahwa kualitas modal manusia (tingkat pendidikan yang lebih tinggi dan status kesehatan yang lebih baik) berpengaruh positif dan signifikan dalam meningkatkan pertumbuhan produktivitas.

\subsection{Pengaruh Investasi Modal Fisik Terhadap Pertumbuhan Produktivitas}

Pengaruh variabel investasi modal fisik memiliki pengaruh yang positif dan signifikan sebagai salah satu faktor determinan terhadap peningkatan produktivitas. Dengan nilai probabilitas t-statistik sebesar 3.799684. Variabel investasi modal fisik positif dan signifikan mempengaruhi tingkat produktivitas suatu daerah dengan nilai koefisien regresi variabel investasi sebesar 0.314096. Hal ini mengindikaskan bahwa setiap perubahan investasi sebesar $1 \%$ yang diproksi dengan pembentukan modal tetap bruto (PMTB) memberikan dampak terhadap 
peningkatan produktivitas daerah sebesar $0,31 \%$ ceteris paribus. Adanya pengaruh positif dan signifikan investasi modal manusia terhadap peningkatan produktivitas menunjukkan bahwa investasi pada pembentukan modal tetap bruto (PMTB) mengalami peningkatan baik secara nominal maupun riil. Dimana secara keseluruhan pertumbuhan PMTB dan kurun waktu 20132017 meningkat dari 2,24 persen menjadi 2,33 persen. Adapun sub komponen bangunan merupakan komponen dengan proporsi terbesar dalam pembentukan modal tetap. Pertumbuhan di sektor bangunan meskipun cenderung meningkat tetapi polanya relatif stabil bila dibandingkan dengan pertumbuhan sub komponen PMTB lainnya. Sedangkan proporsi non bangunan terhadap total PMTB relatif berfluktuasi selama periode 2013-2017. Perubahan yang terjadi pada proporsi tersebut tidak lepas dari pengaruh pertumbuhan yang terjadi pada masing-masing sub komponen PMTB tersebut. Secara umum, selama kurun waktu tahun 2013-2017 pertumbuhan investasi modal fisik mengalami fluktuasi di mana pertumbuhan tertinggi terjadi pada tahun 2015 yang mencapai besaran angka 5,70 persen dan pertumbuhan terendah terjadi pada tahun 2016 yaitu hanya sebesar 0,54 persen.

Koefisien variabel investasi modal fisik memiliki arah positif dan secara statistik signifikan pada tingkat signifikansi 0,05 persen. Hasil penelitian ini sesuai dengan hipotesis, bahwa investasi memiliki pengaruh secara parsial dalam mempengaruhi pertumbuhan ekonomi di Provinsi Kalimantan Barat. Temuan ini sejalan dengan yang dikemukakan oleh Solow bahwa modal fisik adalah determinan output perekonomian yang penting karena persediaan modal bisa berubah sepanjang waktu, dan perubahan itu bisa mengarah pada pertumbuhan ekonomi. Investasi sebagai bagian dari modal akan mengacu pada pengeluaran untuk perluasan usaha dan peralatan baru, dan hal itu menyebabkan persediaan modal bertambah sehingga dapat mendorong pertumbuhan ekonomi.

Investasi sebagai salah satu komponen pendorong pertumbuhan ekonomi. Secara teori, meningkatnya tingkat investasi akan berdampak terhadap meningkatnya pertumbuhan ekonomi, tingkat investasi yang meningkat akan merangsang dunia usaha atau perusahaan untuk meningkatkan produksinya, sehingga produksi perkapita pun akan meningkat. Pemerintah sebagai pemegang kebijakan dan regulator bertugas untuk menentukan investasi mana yang paling baik ditanamkan dan yang berpotensi untuk dikembangkan, dalam hal ini investasi yang memiliki keunggulan dan daya saing serta yang bersifat padat karya sangat diharapkan untuk mengurangi tingkat pengangguran dan meningkatkan output perkapita yang ada di Provinsi Kalimantan Barat.

Menurut Saepudin (2013), pertumbuhan investasi merupakan elemen penting dalam proses pertumbuhan ekonomi di suatu negara/wilayah. Hal ini ditunjukkan oleh hasil estimasi, bahwa pertumbuhan investasi berpengaruh positif dan signifikan terhadap pertumbuhan ekonomi provinsi di Indonesia. Hubungan antara investasi dan pertumbuhan ekonomi adalah koheren (hubungan searah); jika pertumbuhan investasi meningkat, pertumbuhan ekonomi juga akan meningkat. Ini sejalan dengan prinsip dalam pertumbuhan ekonomi bahwa pertumbuhan modal (investasi) sejalan dengan pertumbuhan ekonomi (output). Pertumbuhan modal berkorelasi positif dengan pertumbuhan ekonomi. Mankiw et al. (1992) melakukan penelitian menggunakan 2 jenis modal, yaitu modal fisik dan modal sumber daya manusia di 98 negara pada periode waktu 1960-1985 sebagai rata-rata. Dari kedua modal, investasi fisik memainkan peran yang lebih penting dalam pertumbuhan ekonomi dibandingkan dengan investasi sumber daya manusia. Mereka juga berpendapat bahwa semakin tinggi tingkat struktur pembangunan sebuah negara, 
modal sumber daya manusia menjadi lebih penting dalam mendorong pertumbuhan ekonomi. Dalam sebuah studi Ranis, Frances, \& Alejandro (2000), pertumbuhan pendapatan per kapita secara signifikan dipengaruhi investasi domestik. Pengaruh positif dari variabel investasi modal fisik terhadap produktivitas adalah dalam sesuai dengan penelitian oleh Soejoto et al. (2017) di Asia Tenggara, studi oleh Reza \& Widodo (2013) di Indonesia, studi oleh Xiaoqing (2005) di Cina, tetapi bertentangan dengan studi oleh Olayemi (2012) di Nigeria yang menyatakan bahwa pembentukan Modal Bruto menunjukkan hubungan negatif jangka panjang dengan tingkat produktivitas sektor industri.

\section{SIMPULAN}

Pengaruh investasi modal manusia yang diproksi dengan rata-rata lama sekolah dan angka partisipasi sekolah tingkat SMA terhadap produktivitas menujukkan pola hubungan yang searah dengan nilai koefisien regresi sebesar 0,238 untuk rata-rata lama sekolah (RLS) dan 0,167 untuk angka partisipasi sekolah (APS). Artinya dalam jangka panjang seiring meningkatnya ratarata lama sekolah dan angka partisipasi sekolah akan berdampak pada peningkatan pertumbuhan produktifitas ekonomi daerah. Namun hasil uji signifikansi (uji t) untuk kedua variabel tersebut selama periode penelitian di Kalimantan Barat menunjukkan hubungan yang tidak signifikan. Sedangkan pengaruh tingkat kesehatan yang diproksi dengan angka harapan hidup terhadap produktivitas menujukkan pola hubungan yang searah dengan nilai koefisien regresi sebesar 0,115 . Artinya dalam jangka panjang seiring bertambahnya umur panjang dan hidup sehat akan meningkatkan produktifitas. Namun hasil uji signifikansi (uji t) selama periode penelitian di Kalimantan Barat menunjukkan hubungan yang tidak signifikan.

Investasi modal fisik yang diproksi dengan pembentukan modal tetap bruto (PMTB) terhadap produktivitas menujukkan pola hubungan yang searah dengan nilai koefisien regresi sebesar 0,314 . Artinya dalam jangka panjang bertambahnya stok capital baik modal maupun peralatan-peralatan seperti mesin-mesin, dan teknologi yang digunakan oleh para pekerja akan meningkatkan pertumbuhan produktifitas bagi daerahnya. Dan hasil uji signifikansi (uji t) selama periode penelitian di Kalimantan Barat menunjukkan hubungan yang signifikan. Nilai besaran koefisien investasi modal manusia lebih kecil dibandingkan dengan besaran koefisien investasi modal fisik. Artinya di daerah Kabupaten/Kota Provinsi Kalimantan Barat dalam meningkatkan produktivitas ekonomi daerah lebih diutamakan peran penting investasi modal fisik (PMTB) dari pada peran modal manusianya.

\section{UCAPAN TERIMA KASIH}

Penulis mengucapkan terima kasih kepada Pimpinan Fakultas Ekonomi dan Bisnis Universitas Tanjungpura (FEB UNTAN) yang telah membiayai riset ini dan pihak-pihak terkait yang telah memberikan dukungan terlaksananya kegiatan penelitian.

\section{DAFTAR PUSTAKA}

A. McEachern, W. (2000). Ekonomi Makro: Pendekatan Kontemporer. Jakarta: Salemba Empat.

Ahmadi, M. S., Naji, A., \& Jandaghi, F. (2010). Bounded Convergence Test Method, the Interaction between Human Capital and Total Factor Productivity in Iran. Journal of 
Development Economics, 1(1), 31-58.

Aigbokhan, B. O., Imahe, E., \& Ailemen, M. I. (2017). Education Expenditure and Human Capital Development in Nigeria: Any Correlation So Far. Ekpoma, Nigeria.

Aimon, H. (2012). Produktivitas, Investasi Sumberdaya Manusia, Investasi Fisik, Kesempatan Kerja Terhadap Kemiskinan dan Pertumbuhan Ekonomi di indonesia. Jurnal Kajian Ekonomi, 1(1).

Aldosari, M., Ibrahim, Y., Manab, N. A., \& Islam, R. (2014). Foreign Workers Satisfaction with Cooperative Health Insurance in Saudi Arabia. Advances in Natural and Applied Sciences, 8(9), 101-108.

Amassoma, D., \& Nwosa, P. I. (2018). Investment in Human Capital and Economic Growth in Nigeria: A Causality Approach. Canadian Journal of Social Research, 7(4), 114-120.

Amassoma, Ditimi, \& Inzagi, N. P. (2011). Investment in Human Capital and Economic Growth in Nigeria Using a Causality Approach. Canadian Social Science. https://doi.org/10.3968/j.css.

Anyanwu, S. O., Adam, J. A., Obi, B., \& Yelwa, M. (2015). Human Capital Development and Economic Growth in Nigeria. Journal of Economics And Sustainable Development, 6(14), 16-26. https://doi.org/10.11648/j.jwer.20180702.12

Arshad, M. N. M., \& Malik, Z. A. (2015). Quality of Human Capital and Labor Productivity: a Case of Malaysia. International Journal of Economics, Management and Accounting, 23(1), 37-55.

Bassanini, A., S, S., \& H, P. (2001). Economic Growth: The Role of Pilicies and Institutions. Panel Data Evidence from OECD Countries (No. 283). France.

Becker, G. S. (1993). Human Capital: A Theoretical and Empirical Analysis with Special Reference to Education. University of Chicago Press.

Bloom, D. E., Canning, D., \& Sevilla, J. (2001). The Effect of Health on Economic Growth: Theory and Evidence. Cambridge.

Brata, A. . (2002). Pembangunan Manusia dan Kinerja Ekonomi Regional di Indonesia. Jurnal Ekonomi Pembangunan, 7(2).

Chotib, M., Suharto, B., \& Lucik. (2019). Optimization of Human Capital Development on Economic Growth and Poverty in East Java. International Journal of Scientific and Technology Research, 8(9), 652-657.

Eigbiremolen, G. O., \& Anaduaka, U. S. (2014). Human Capital Development and Economic Growth: The Nigeria Experience. International Journal of Academic Research in Business and Social Sciences, 4(4), 25-35. https://doi.org/10.6007/ijarbss/v4-i4/749

Ezoji, A., Assari, A., Mahdavi, M. R. V., \& Jahangard, E. (2019). The Impact of Human Capital (Health and Education) on Labor Productivity; a Composite Model Approach - a Case Study of Iran. Iranian Economic Review, 23(2), 373-397. https://doi.org/10.22059/ier.2019.70287

Farah, A., \& Sari, E. P. (2014). Modal Manusia dan Produktivitas. JEJAK Journal of Economics 
and Policy, 7(1), 22-28. https://doi.org/10.15294/jejak.v7i1.3840

Fuente, A. de la. (2011). Human Capital and Productivity: Barcelona Graduate School of Economics. Retrieved from http://ideas.repec.org/p/bge/wpaper/530.html

Gujarati, D. N. (2004). Basic Econometrics. (Fourth Edi, Vol. 82). https://doi.org/10.2307/2230043

Hakooma, M. R., \& Seshamani, V. (2017). The Impact of Human Capital Development on Economic Growth in Zambia: An Econometric Analysis. International Journal of Economics, Commerce and Management, 4(4), 71-87.

Hansen, C. W. (2013). Health and Development: A Neoclassical Perspective. Journal of Human Capital, 7(3), 274-295.

Islam, R., Ghani, A. B. A., Kusuma, B., \& Theseira, B. B. (2016). Education and Human Capital Effect on Malaysian Economic Growth. International Journal of Economics and Financial Issues, 6(4), 1722-1728.

Ismail, R., Saukani, M. N. M., \& Bakar, N. T. A. (2014). Human Capital and Regional Wage Differentials in Malaysia. Actual Problems of Economics, 5(155), 328-338.

Ismail, R., \& Yussof, I. (2010). Human Capital and Income Distribution in Malaysia: A Case Study. Journal of Economic Cooperation and Development, 31(2), 25-46.

Kataoka, M. (2013). Allocation of Human Capital Across Regions and Economic Growth in Indonesia.

Leeuwen, B. Van. (2007). Human Capital and Economic Growth in India, Indonesia and Japan. Netherlands.

Maku, O. E., Ajike, E. O., \& Chinedu, S. C. (2019). Human Capital Development and Macroeconomic Performance in Nigeria: An Autoregressive Distributed Lag ( ARDL ) Approach. Etikonomi, $18(2)$,

185-196. https://doi.org/http//dx.doi.org/10.15408/etk.v18i2.11701

Mankiw, G., R., D., \& Weil., D. N. (1992). A Contribution to the Empirics of Economic Growth. The Quarterly Journal of Economics, 107(2), 407-437.

Mankiw, N. G. (2005). Macroeconomics (6th Edition). New York.

Mankiw, N. G. (2006a). Makro Ekonomi (Edisi Keenam). Jakarta: Erlangga.

Mankiw, N. G. (2006b). Principles of Economics. Jakarta: Salemba Empat.

Marvelous, A. I., Baba, I. A. D., \& Emily, G. J. (2017). Education Sector and Economic Growth in Nigeria: an Impact Analysis. International Journal of Advanced Studies in Economics and Public Sector Management, 5(3), 58-69. Retrieved from http://internationalpolicybrief.org/

Mushkin, S. J. (1962). Health as an Investment. Journal of Political Economy. https://doi.org/10.1086/258730

Nicholson, W. (2002). Mikroekonomi Intermediate (Edisi Kede). Jakarta: Erlangga.

Olayemi, S.-O. O. (2012). Human Capital Investment and Industrial Productivity in Nigeria. 
International Journal of Humanities and Social Science, 2(16), 298-307. https://doi.org/10.4314/afrrev.v9i1.4

Oluwadamilola, O., Akinyemi, O., \& Adediran, O. (2018). Human Capital Development and Inclusive Growth: Implications for Achieving SDG-4 in Nigeria. African Population Studies, 32(1), 4088-4096. https://doi.org/10.11564/32-1-1180

Oluwatobi, S. O., \& Ogunrinola, O. I. (2011). Government Expenditure on Human Capital Development: Implications for Economic Growth in Nigeria. Journal of Sustainable Development, 4(3), 72-80. https://doi.org/10.5539/jsd.v4n3p72

Ozekhome, H. O. (2018). Is Human Capital Accumulation A Growth Driver In Nigeria? An Empirical Investigation. Oradea Journal of Business and Economics, 3(2), 66-77. https://doi.org/10.1017/CBO9781107415324.004

Raeispour, A., \& Pajooyan, J. (2013). A Survey on Public Health Expenditure Investment Effects to Economic Growth \& Productivity in Iran: A Regional Approach. The Journal of Planning and Budgeting, 18(4), 43-68.

Rangongo, M. F., \& Ngwakwe, C. C. (2019). Human Capital Investment and Economic Growth: A Test of Endogenous Growth Theory in Two Developing Countries. Acta Universitatis Danubius CE, 15(Special issue 1), 92-107.

Ranis, G., Frances, S., \& Alejandro, R. (2000). Economic Growth and Human Development. World Development, 28(2), 197-219.

Reza, F., \& Widodo, T. (2013). The Impact of Education on Economic Growth in Indonesia. Journal of Indonesian Economy and Business, 28(1), 23-44. https://doi.org/10.30543/71(2018)-4

Saepudin, T. (2013). Growth of Human Capital and Inter Regional Economic Growth in Indonesia.

Saha, S. (2013). Impact of Health on Productivity Growth in India. International Journal of Economics, Finance and Management, 2(4), 303-312.

Samuelson, P. A., \& Nordhaus, W. D. (2003). Ilmu Makro Ekonomi. Jakarta: PT. Media Edukasi.

Schultz, T. W. (1961). Investment in Human Capital. American Economic Review, 51, 1-17.

Shahraki, M., \& Ghaderi, S. (2015). Decision to Work or Study among Child Laborers in Iran. Quarterly Journal of Quantitative Economics, 9(4), 67-89.

Šniukiene, A. M., \& Matuzeviciute, K. (2018). Impact of Human Capital Development on Productivity Growth in Eu Member States. Business, Management and Education, 16(1), 1-12. https://doi.org/https://doi.org/10.3846/bme.2018.66

Soejoto, A., Cahyono, H., \& Solikhah, N. (2017). Effect of Solow Variable to the Economic Growth in Southeast Asia Ady. International Journal of Economics and Financial Issues, 7(2), 277-282.

Solow, R. M. (1956). A Contribution to the Theory of Economic Growth. The Quarterly Journal of Economics, 70(1), 65-94. https://doi.org/https://doi.org/10.2307/1884513

Soltanisehat, L., Alizadeh, R., \& Mehregan, N. (2019). Research and Development Investment 
and Productivity Growth in Firms with Different Levels of Technology. Iranian Economic Review, 23(4), 795-818. https://doi.org/10.22059/ier.2019.72991

Tang, C., Foon, L., \& Yew, W. (2011). The Causal Relationship between Health and Education Expenditures in Malaysia. Theoretical and Applied Economics, 8(561), 61-74.

Todaro, M. P. (2000). Pembangunan Ekonomi di Dunia Ketiga. Jakarta: Erlangga.

Todaro, M. P., \& Smith, S. C. (2006a). Economic development 8th edition. Manila, Philippines: Pearson South Asia Pte. Ltd.

Todaro, M. P., \& Smith, S. C. (2006b). Pembangunan Ekonomi (Edisi Kese). Jakarta: Erlangga.

Vidyattama, Y. (2010). A Search for Indonesia's Regional Growth Determinants. ASEAN Economic Bulletin. https://doi.org/10.1355/ae27-3c

Wahyudi, S. T. (2016). Konsep dan Penerapan Ekonometrika Menggunakan E-views. Jakarta: PT. Raja Grafindo Persada.

Wang, Y, \& Yau, Y. (2002). Sources of China's Economic Growth 1952 - 1999 Incorating Human Capital Accumulation. China Economics Review 116.

Wang, Ying, \& Liu, S. (2016). Education, Human Capital and Economic Growth: Empirical Research on 55 Countries and Regions (1960-2009). Theoretical Economics Letters, 06(02), 347-355. https://doi.org/10.4236/tel.2016.62039

Werigbelegha, A. P., \& Peter, E. G. (2018). Empirical Investigation of Human Capital Investments and Its Effect on Economic Growth in Nigeria (1990-2017). European Journal of Business and Innovation Research, 6(6), 73-80.

Widarjono, A. (2007). Ekonometrika: Teori dan Aplikasi Untuk Ekonomi dan Bisnis (Edisi Kedu). Yogyakarta: Ekonisia.

Xiaoqing, X. (2005). Investment in Physical Capital, Investment in Health and Economic Growth in China. Investment Management and Financial Innovations, 2(1), 23-29. 